\title{
Lignin's ability to nucleate ice via immersion freezing and its stability towards physicochemical treatments and atmospheric processing
}

\author{
Sophie Bogler ${ }^{1}$ and Nadine Borduas-Dedekind ${ }^{1,2}$ \\ ${ }^{1}$ Institute for Biogeochemistry and Pollutant Dynamics, ETH Zurich, Zurich, 8092, Switzerland \\ ${ }^{2}$ Institute for Atmospheric and Climate Sciences, ETH Zurich, Zurich, 8092, Switzerland
}

Correspondence: Nadine Borduas-Dedekind (nadine.borduas@usys.ethz.ch)

Received: 12 June 2020 - Discussion started: 25 June 2020

Revised: 2 October 2020 - Accepted: 12 October 2020 - Published: 30 November 2020

\begin{abstract}
Aerosol-cloud interactions dominate the uncertainties in current predictions of the atmosphere's radiative balance. Specifically, the ice phase remains difficult to predict in mixed-phase clouds, where liquid water and ice coexist. The formation of ice in these clouds originates from heterogeneous ice nucleation processes, of which immersion freezing is a dominant pathway. Among atmospheric surfaces capable of forming a template for ice, mineral dust, biological material and more recently organic matter are known to initiate freezing. To further our understanding of the role of organic matter in ice nucleation, we chose to investigate the ice nucleation (IN) ability of a specific subcomponent of atmospheric organic matter, the biopolymer lignin. Ice nucleation experiments were conducted in our custom-built freezing ice nuclei counter (FINC) to measure freezing temperatures in the immersion freezing mode. We find that lignin acts as an ice-active macromolecule at temperatures relevant for mixed-phase cloud processes (e.g. $50 \%$ activated fraction up to $-18.8^{\circ} \mathrm{C}$ at $200 \mathrm{mg} \mathrm{C} \mathrm{L}^{-1}$ ). Within a dilution series of lignin solutions, we observed a non-linear effect in freezing temperatures; the number of IN sites per milligram of carbon increased with decreasing lignin concentration. We attribute this change to a concentration-dependant aggregation of lignin in solution. We further investigated the effect of physicochemical treatments on lignin's IN activity, including experiments with sonication, heating and reaction with hydrogen peroxide. Only harsh conditions such as heating to $260^{\circ} \mathrm{C}$ and addition of a mixture with a ratio of $1: 750$ of grams of lignin to millilitres of hydrogen peroxide were able to decrease lignin's IN activity to the instrument's back-
\end{abstract}

ground level. Next, photochemical and ozone bubbling experiments were conducted to test the effect of atmospheric processing on lignin's IN activity. We showed that this activity was not susceptible to changes under atmospherically relevant conditions, despite chemical changes observed by UV-Vis absorbance. Our results present lignin as a recalcitrant IN-active subcomponent of organic matter within, for example, biomass burning aerosols and brown carbon. They further contribute to the understanding of how soluble organic material in the atmosphere can nucleate ice.

\section{Introduction}

To reduce modelling uncertainties of radiative forcing from aerosol-cloud interactions, an improved understanding of ice formation in the atmosphere is necessary (Stocker et al., 2013). Atmospheric ice crystals influence cloud properties by altering their microphysical and radiative properties, thereby affecting precipitation patterns and cloud lifetime (Storelvmo et al., 2011). In fact, the majority of precipitation originates from the ice phase (Mülmenstädt et al., 2015). In mixed-phase clouds, where water and ice coexist, ice crystals grow at the expense of supercooled water droplets through the Wegener-Bergeron-Findeisen process. As the saturation water vapour pressure over ice is lower than over water, ice crystals grow and consequently dominate the phase distribution of water in the cloud (Korolev and Field, 2008). Ice-nucleating particles (INPs) are necessary to induce freezing at warmer temperatures via a 
heterogeneous freezing pathway since homogeneous freezing of nanolitres of cloud water droplets becomes instantaneous only at temperatures below $-38^{\circ} \mathrm{C}$. In mixed-phase clouds, the immersion-freezing pathway dominates heterogeneous freezing and occurs when solid or dissolved INPs initiate freezing from within a supercooled cloud droplet (Hoose and Möhler, 2012; Knopf et al., 2018). It remains crucial to study the pathways of ice crystal formation in these clouds to advance our quantitative understanding of warming and cooling factors contributing to the aerosol-cloud radiative effects (Storelvmo et al., 2011).

In this study, we focused on the ice nucleation (IN) abilities of organic matter. We define organic matter as a generic term for material that is made of covalently bonded $\mathrm{C}, \mathrm{H}, \mathrm{O}$, $\mathrm{N}$ and $\mathrm{S}$ and includes biological material as a subset of organic matter. Organic aerosols are ubiquitous in the environment (Jimenez et al., 2009) and their ice-nucleating ability is highly variable and depends on their chemical composition (Knopf et al., 2018). Recently, dissolved organic matter from lakes and rivers have been identified as efficient soluble INPs (Borduas-Dedekind et al., 2019; Knackstedt et al., 2018; Moffett et al., 2018). The analytical challenge, however, of resolving the chemical composition of complex organic matter hinders our ability to identify the specific functional group, chemical moieties or conformations acting as a surface to form a template for ice. Thus, detailed elucidation of the IN-active component of organic matter, including organic aerosols, can help improve ice crystal concentration predictions in mixed-phase clouds.

We chose to reduce sample complexity by investigating the IN activity of a specific commercially available subcomponent of organic aerosols, the biopolymer lignin. Indeed, lignin is the second most abundant organic polymer on earth after cellulose. An estimated $30 \%$ of the organic carbon present in our biosphere is part of this polymer (Boerjan et al., 2003). Lignin functions as an essential structural component in the cell walls of plants where it builds a complex matrix with cellulose and hemicellulose (Faraji et al., 2018). As such, lignin provides stability, enables the efficient transport of water and solutes through plant stems, and protects the plant against external pathogens (Boerjan et al., 2003). The biopolymer is best described as a complex class of aromatic heteropolymers built from three main precursor monomers of hydroxy-cinnamyl alcohols: namely $p$-coumaryl alcohol, coniferyl alcohol and sinapyl alcohol (Fig. 1) (Vanholme et al., 2019). The monolignols are most commonly linked through a stepwise and entirely chemically controlled polymerization in irregular patterns via ether bonds $(\beta-\mathrm{O}-4, \alpha-$ O-4) or carbon-carbon bonds (Chandra and Madakka, 2019; Ralph et al., 2019) (Fig. 1). Evidently, a variety of formation pathways exist, which likely increases the polymer's structural heterogeneity and its robustness against degradation and enables its protective role in cell wall structure.

Lignin is emitted into the atmosphere through three main pathways: (1) sea and lake spray aerosols, (2) soil dust, and

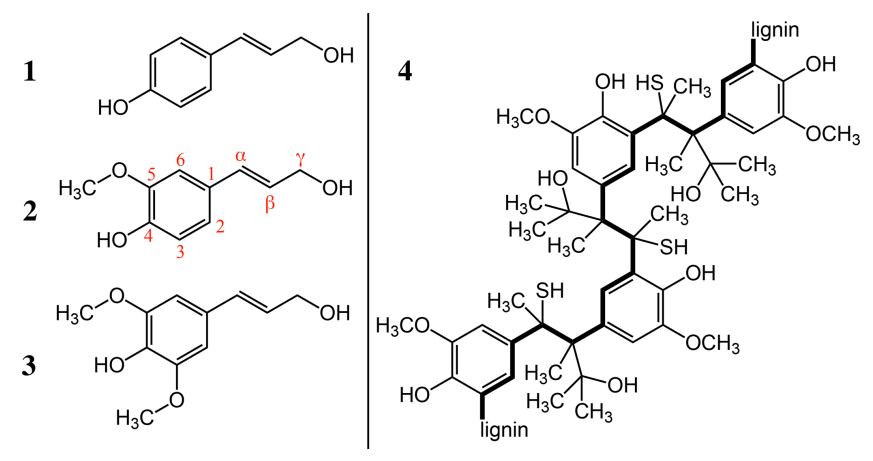

Figure 1. Main precursor monomers of lignin are the following: (1) p-coumaryl alcohol, (2) coniferyl alcohol and (3) sinapyl alcohol. (4) An example of the polymeric structure provided by the supplier Sigma-Aldrich.

(3) biomass burning plumes. (1) Lignin is part of the organic matter in lakes, rivers and oceans as plant debris. This material enters the water body either via runoff from the watershed or through deposition, e.g. from overhanging plants. The production of lake, river or sea spray aerosol transfers this biological material including lignin and other biogenic macromolecules into the atmosphere (Axson et al., 2016; Knackstedt et al., 2018; Meyers-Schulte and Hedges, 1986; Olson et al., 2019; Slade et al., 2010; Zark and Dittmar, 2018). The aerosols containing this complex organic matter have been shown to nucleate ice at temperatures relevant for mixed-phase clouds (Borduas-Dedekind et al., 2019; Knackstedt et al., 2018; Moffett et al., 2018). (2) Soils can be a source of lignin-containing organic matter to the atmosphere. Wind erosion can transport soil dust and plant fragments into the atmosphere, e.g. during agricultural harvesting (Suski et al., 2018; Tobo et al., 2014). Studies from, for example, Conen et al. (2011), Hill et al. (2016), Pratt et al. (2009), Suski et al. (2018) and Tobo et al. (2014) have demonstrated the potential of this material to act as INPs before. Further, lignin could be part of organic coatings on soil minerals known to be INPs and thereby influence the mineral's IN activity. Indeed, examinations of organic coatings on minerals have revealed the importance of the organic component (Augustin-Bauditz et al., 2016; Birkel et al., 2002; Perkins et al., 2020). (3) Lignin also reaches the atmosphere through biomass burning processes, where its monomeric pyrolysis products are common tracers of organic matter (Shakya et al., 2011; Simoneit, 2002). In addition, large fractions of polymeric forms of lignin remain present in biomass burning organic aerosols even after pyrolysis (Myers-Pigg et al., 2016; Shakya et al., 2011; Stefenelli et al., 2019). In a study by Myers-Pigg et al. (2016), up to $73 \%-91 \%$ of the lignin material in a wildfire smoke plume was in polymeric form. We therefore expect lignin to be present and relevant for aerosolcloud interactions. The IN potential of these biomass burning aerosols has also been investigated before (e.g. McCluskey et 


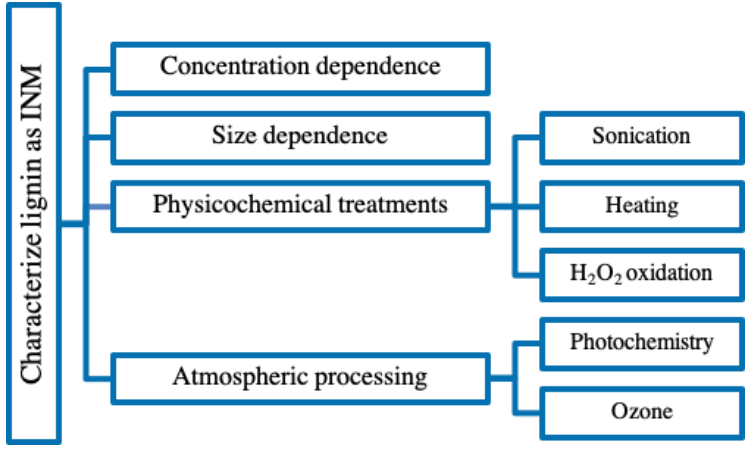

Figure 2. Overview of conducted experiments to characterize lignin as an IN macromolecule (INM).

al., 2014; Prenni et al., 2012). But results from field and laboratory studies remain contradictory, and further elucidation requires more details about particle composition and morphology (Bond et al., 2013; Kanji et al., 2017).

An assessment of the IN activity of plant-derived material including lignin and complex ambient samples has recently been initiated by Steinke et al. (2020). This study concluded that the individual plant-derived organic compounds show lower IN activity than complex ambient plant-derived samples. In fact, lignin was one of the least IN efficient components in plant-derived material with IN activity surface density values between $10^{8}$ and $10^{9} \mathrm{~m}^{-2}$, i.e. 2 orders of magnitude lower than the complex samples. With our study, we aim to continue the discussion of IN activity in plant-derived material and macromolecules in immersion freezing (Pummer et al., 2015) and contribute IN results for lignin in more detail. We aim to improve our understanding of organic matter's IN abilities on a molecular level by investigating lignin as a model organic aerosol component. To determine lignin's possible impact on aerosol-cloud interactions, we characterized its IN activity in our drop-freezing ice nuclei counter (FINC; Miller et al., 2020). Additionally, we extended the investigation to the effects of physicochemical treatments such as sonication, heating, reaction with hydrogen peroxide and atmospheric processing, such as photochemistry and oxidation by ozone, on lignin's IN activity (Fig. 2). Although we expected lignin, as a subcomponent of organic matter, to be reactive towards these processing treatments, we found that it was particularly recalcitrant.

\section{Materials and methods}

\subsection{Lignin sample preparation}

Lignin solutions were prepared from powder kraft lignin (471003, Sigma-Aldrich, average $M_{\mathrm{w}} 10000 \mathrm{~g} \mathrm{~mol}^{-1}$, Fig. 1) dissolved in molecular biology reagent water (hereafter termed background water, W4502, Sigma-Aldrich, Germany) to minimize contamination from the solvent. Tar- geted carbon concentrations were based on a carbon content of $50 \%$ resulting from the producer's elemental analysis data $(47 \%-51 \%)$. As specified by the producer, this technical kraft lignin has a remaining sulfur content $\leq 3.6 \%$. This sulfur is introduced into lignin as an impurity during the delignifying kraft process in wood pulping by addition to double bonds in its aliphatic carbon chain (Lin and Dence, 1992). Sample solutions were stored in amber glass vials at $4{ }^{\circ} \mathrm{C}$ in between processing and measurements. Sterile conditions are important to minimize background freezing and thus all solutions were prepared in a calibrated laminar flow hood (Labculture ${ }^{\circledR}$ class II, type A2 biological safety cabinets, ESCO). In addition, all glassware was cleaned before use by rinsing three times with distilled water and three times with acetone followed by drying in the oven at $120^{\circ} \mathrm{C}$ for a minimum of $1 \mathrm{~h}$.

\subsection{Analytical chemistry techniques}

\subsubsection{UV-Vis spectrometry}

To characterize the chromophores within lignin, we measured the absorbance of aqueous sample solutions with UVVis spectrometry (Varian Cary 100 Bio, Agilent). A baseline correction with background water was applied to all sample measurements.

\subsubsection{Ion chromatography}

Acetic acid, formic acid, oxalic acid and pyruvic acid were quantified via ion chromatography (DX-320, Thermo Scientific, USA) using the method from Borduas-Dedekind et al. (2019). Briefly, we used the instrument with an EG40 eluent gradient generator, a Dionex Ion-Pac AG11-HC RFIC (reagent-free ion chromatography) $4 \mathrm{~mm}$ column and a guard column, a Dionex AERS (anion electrolytically regenerated suppressor) $5004 \mathrm{~mm}$ electric suppressor and an electrical conductivity detector. The $\mathrm{KOH}$ gradient was set as follows: 0 to $11 \mathrm{~min}, 1 \mathrm{mmol} \mathrm{L}^{-1}$; 11 to $37 \mathrm{~min}, 1$ to $40 \mathrm{mmol} \mathrm{L}^{-1}$; 37 to $38 \mathrm{~min}, 40 \mathrm{mmol} \mathrm{L}^{-1}$; 38 to $41 \mathrm{~min}, 1 \mathrm{mmol} \mathrm{L}^{-1}$. The retention times of the acids were 7.9, 10.6, 13.5 and $26.2 \mathrm{~min}$ for acetic acid, formic acid, pyruvic acid and oxalic acid, respectively. The calibration curves for each acid are in the Supplement (Fig. S1). Note that none of our samples had detectable amounts of pyruvic acid.

\subsection{Treatment experiments}

\subsubsection{Sonication}

Lignin solutions concentrated at 20 and $200 \mathrm{mg} \mathrm{C} \mathrm{L}^{-1}$ were sonicated in $10 \mathrm{~mL}$ volumetric flasks for up to $60 \mathrm{~min}$ in a sonicator (ultrasonic cleaner, VWR, USA) at $30^{\circ} \mathrm{C}$. 


\subsubsection{Heating}

Lignin was heated as a powder in $20 \mathrm{mg}$ aliquots for $3 \mathrm{~h}$ at temperatures ranging from room temperature $\left(21^{\circ} \mathrm{C}\right)$ to $300^{\circ} \mathrm{C}$. After heating, background water was subsequently added to reach a carbon content of $200 \mathrm{mg} \mathrm{C} \mathrm{L}^{-1}$. It was necessary to heat lignin in powder form, as heating in solution would have led to unquantified concentration changes due to the evaporation of water. To test the ice-nucleating ability of the insoluble by-products generated during the heating, vacuum filtration $\left(0.22 \mu \mathrm{m}\right.$ MCE membrane, MF-Millipore $\left.{ }^{\mathrm{TM}}\right)$ and sterile syringe filtration $(0.22 \mu \mathrm{m}$ PES membrane, TPP, Switzerland) were used to separate the soluble from the insoluble heated lignin.

\subsubsection{Hydrogen peroxide reaction}

The chemical treatment with hydrogen peroxide $\left(\mathrm{H}_{2} \mathrm{O}_{2}\right)$ was adapted from Paramonov et al. (2018). Solid lignin samples reacted with $\mathrm{H}_{2} \mathrm{O}_{2}$ ( $35 \mathrm{wt} \%$ aqueous solution, SigmaAldrich) in ratios varying from 1:5 to $1: 750$ (grams lignin to millilitres $\mathrm{H}_{2} \mathrm{O}_{2}$ ) in a glass vial. Using a carbon content of lignin of $50 \%$, based on the information from the supplier, these ratios approximately equate to 1.2 times to 180 times molar excess of $\mathrm{H}_{2} \mathrm{O}_{2}$ to carbon. The samples were left to react overnight and then diluted accordingly with background water to reach a concentration of $200 \mathrm{~m} \mathrm{C} \mathrm{L}^{-1}$ before determining the IN activity of the solution. To ensure the reaction with hydrogen peroxide was complete and no additional change to the IN activity was introduced, one set of samples (ratios 1:5, 1:50,1:500) was left to react for an additional time period of $3 \mathrm{~d}$ before dilution to $200 \mathrm{mg} \mathrm{C} \mathrm{L}^{-1}$.

\subsubsection{Size filtration}

To classify the size fraction of the lignin polymer responsible for IN activity, lignin sample solutions were filtered with sterile syringes through $0.02 \mu \mathrm{m}$ (inorganic membrane, Whatman, Anotop) and $0.22 \mu \mathrm{m}$ (PES membrane, TPP, Switzerland) filters. The filters were first rinsed with $30 \mathrm{~mL}$ Milli-Q water and then rinsed with $10 \mathrm{~mL}$ background water prior to filtration of $10 \mathrm{~mL}$ of sample. Freezing experiments with cellulose acetate filters $(0.2$ and $0.45 \mu \mathrm{m}, \mathrm{VWR}, \mathrm{USA})$ and a PTFE membrane filter $(0.2 \mu \mathrm{m}$, BGB, USA) showed persistent IN activity similar to lignin's at $20 \mathrm{mg} \mathrm{C} \mathrm{L}^{-1}$ in our ice nucleation setup after rinsing (Fig. S2). Therefore, the use of these filters was discontinued for this study.

\subsection{Atmospheric processing experiments}

\subsubsection{Photochemical experiment}

For the photochemical experiments, $9 \mathrm{~mL}$ of a $20 \mathrm{mg} \mathrm{CL}^{-1}$ lignin solution was pipetted in $10 \mathrm{~mL}$ borosilicate test tubes (Pyrex, $15 \times 85 \mathrm{~mm}$, disposable) and placed inside a motorized turntable of a commercial photoreactor (Rayonet,
Southern New England Ultraviolet Co.). The photoreactor was equipped with eight UVB light bulbs (UVB - $3000 \AA$ from Southern New England Ultraviolet Co.) and provided an irradiation as a function of wavelength spectrum peaking at $310 \mathrm{~nm}$ (Fig. S3). The temperature inside the photoreactor is kept stable with a fan at $30-32^{\circ} \mathrm{C}$ for the duration of the experiment (up to $25 \mathrm{~h}$ ). At each time point, test tubes containing sample solution were replaced with test tubes containing either more sample solution or pure Milli-Q water to ensure a constant light path.

\subsubsection{Actinometry}

To quantify the light intensity in the photochemical setup, we conducted an actinometry experiment with the chemical actinometer pyridine/ $p$-nitroanisole (PNA) following the method in Laszakovits et al. (2016) and Borduas-Dedekind et al. (2019). Briefly, a solution containing $20 \mu \mathrm{M}$ of recrystallized PNA and $0.25 \mathrm{mM}$ of pyridine in Milli-Q water was irradiated for $6 \mathrm{~h}$ under the same conditions as the lignin solutions. At different time points, the PNA was quantified via high-pressure liquid chromatography (UltiMate 3000 HPLC, Thermo Fisher Scientific). The system was equipped with a reverse-phase C18 column (Ascentis express, $90 \AA \mathrm{C} 18$, $15 \mathrm{~cm} \times 4.6 \mathrm{~mm}, 5 \mu \mathrm{m}$ ), its guard column and a UV detector. The analyses were performed in isocratic mode using as eluent $50 / 50 \mathrm{~A} / \mathrm{B}$, where $\mathrm{A}$ is $100 \%$ acetonitrile (ACN) and $\mathrm{B}$ is $90 \%$ acetate buffer at $\mathrm{pH} 6$ with $10 \% \mathrm{ACN}$. The eluent was delivered at a flow rate of $1 \mathrm{~mL} \mathrm{~min}^{-1}$, while the sample injection volume was $20 \mu \mathrm{L}$. In these conditions, PNA eluted at $2.98 \mathrm{~min}$ and was detected at $316 \mathrm{~nm}$. A plot of $\ln \left(\mathrm{c}[\mathrm{PNA}] / \mathrm{c}[\mathrm{PNA}]_{0}\right)$ versus time (Fig. S4) provided the pseudo first-order degradation constant for PNA of $k_{\text {deg, } \mathrm{PNA}}=(0.568 \pm 0.004) \mathrm{h}^{-1}$, where the error is the standard deviation of triplicate experiments. Based on $k_{\mathrm{deg}, \mathrm{PNA}}$ and the measured spectral irradiance of the used light bulbs, we calculated the absolute spectral irradiance $I_{\lambda}$ of this photochemistry setup as $I_{\lambda}=(109.94 \pm 0.85) \mathrm{W} \mathrm{m}^{-2}$ (further calculation details are described Sect. S3). Additionally, we determined a conversion factor of 3.14 from the irradiation time in the photoreactor into the equivalent irradiation time in natural sunlight. With this factor, $25 \mathrm{~h}$ irradiation in the photoreactor equates to $6.5 \mathrm{~d}$ of sunlight in the environment, consistent with the atmospheric lifetime of organic aerosols.

\subsubsection{Ozone oxidation setup}

Ozone $\left(\mathrm{O}_{3}\right)$ was generated in situ reaching target concentrations of $100 \mathrm{ppbv}$ and $1 \mathrm{ppmv} \mathrm{O}_{3}$. The $\mathrm{O}_{3}$ concentration was monitored with an ozone monitor (932, BMT Berlin Messtechnik $\mathrm{GmbH}$ ). In detail, compressed ambient air filtered for particles and volatile organic compounds (VOCs) (Druckluft-Filter, AiR Center Diehl) was directed with $1 \mathrm{~L} \mathrm{~min}^{-1}$ into the $\mathrm{O}_{3}$ generator (A2Z Ozone, Inc. USA), where $\mathrm{O}_{3}$ was generated in a fan-cooled corona dis- 
charge tube from atmospheric oxygen. The highly concentrated $\mathrm{O}_{3}$-containing outflow was diluted accordingly with pure nitrogen and then bubbled for up to $6.5 \mathrm{~h}$ at a flow rate of $0.1 \mathrm{~L} \mathrm{~min}^{-1}$ through $20 \mathrm{~mL}$ of lignin solutions using a Teflon tube. Sample solutions with lignin concentrated at $20 \mathrm{mg} \mathrm{C} \mathrm{L}^{-1}$ and background water for controls were prepared in $50 \mathrm{~mL}$ round-bottom flasks and stirred with a magnetic stirrer on a stir plate throughout the oxidation experiment. The background controls ensured that no additional IN-active contamination was introduced into the oxidation setup (Fig. S14). The mass loss through evaporation of solvent following bubble bursting at the solution surface was monitored but remained $<0.5 \mathrm{wt} \%$. The effect on the final solution concentration was therefore minor and not further considered.

\subsection{Ice nucleation experiments}

\subsubsection{Ice nucleation setup}

We used our custom-built freezing ice nuclei counter (FINC) to quantify the heterogeneous ice nucleation of aqueous lignin through immersion freezing (Miller et al., 2020). Briefly, the FINC works by using an ethanol bath to cool the sample solution, and sample freezing is detected based on a change in light intensity in successive pictures captured by a mounted camera throughout cooling (Fig. S5). Each experiment yields 288 freezing temperatures, from $20 \mu \mathrm{L}$ aliquots of sample solution pipetted into 288 Piko PCR tray wells. Sample trays are prepared in a laminar flow hood to minimize sources of contamination. FINC's limit of detection is at $-23.9 \pm 0.6^{\circ} \mathrm{C}$, determined based on repeated freezing experiments with background water (for calculation details see Sect. S4 and Fig. S6). For lignin samples concentrated at $20 \mathrm{mg} \mathrm{CL}^{-1}$ in $20 \mu \mathrm{L}$ aliquots, FINC's uncertainty in the reproducibility is $\pm 0.2^{\circ} \mathrm{C}$ based on 1 standard deviation of the $T_{50}$ values of seven experiments (Fig. S7). Additionally, we report a temperature uncertainty of $0.5^{\circ} \mathrm{C}$ in the freezing temperature of each well in FINC, resulting from the uncertainty in bath temperature and the spread over the three Piko PCR trays. This temperature uncertainty was determined based on thermocouple calibration experiments with ethanol inside the Piko PCR tray wells (Miller et al., 2020). See Sect. S4 for more details about FINC including a picture of the instrument, an exemplary recorded tray picture during a sample run and details regarding data processing.

\subsubsection{Normalization to organic carbon content}

Freezing temperatures were normalized to total organic carbon (TOC) content following Eq. (1) according to Vali (1971, 2008, 2019). The calculation requires the frozen fraction ( $\mathrm{FF}$ as value between 0 and 1 ), the concentration of nonpurgeable carbon (TOC in $\mathrm{mg} \mathrm{C} \mathrm{L}^{-1}$ ) and the sample aliquot in each well $\left(V_{\text {well }}\right.$ is $\left.20 \mu \mathrm{L}\right)$ and results in the $n_{\mathrm{m}}$ value rep-

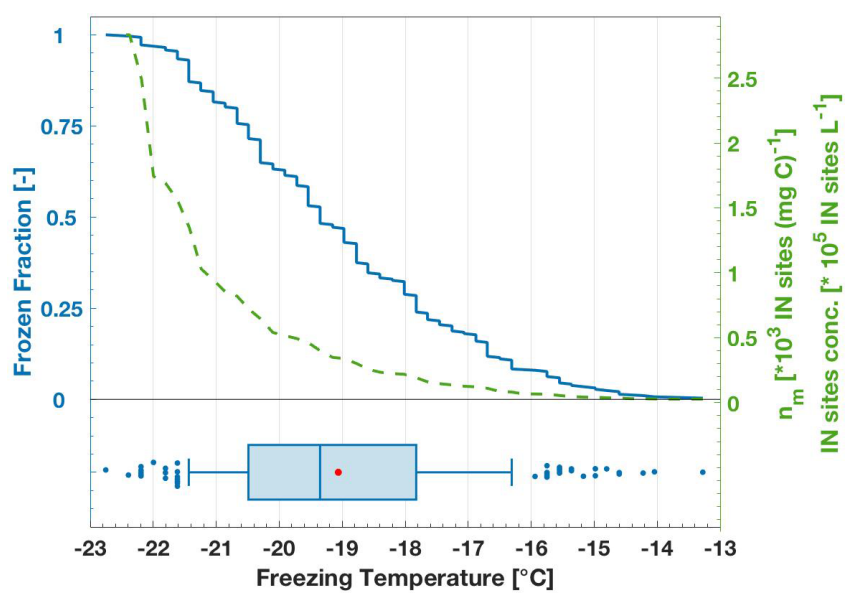

Figure 3. Example of freezing data visualization based on a $100 \mathrm{mg} \mathrm{C} \mathrm{L}^{-1}$ lignin sample solution. The left blue $y$ axis shows the FF curve as a stepwise function of each freezing event; 288 data points are included. The green line curve and the right green $y$ axis show both the INP number concentration and $n_{\mathrm{m}}$ as the INP number concentration normalized to carbon content. Note that the INP concentration and $n_{\mathrm{m}}$ values differ only by the factor of 100 , given by the TOC concentration of $100 \mathrm{mg} \mathrm{CL}^{-1}$ in this example. The FF curve on top is consolidated into a boxplot at the bottom. On the boxplot, the red dot shows the mean value, and the middle blue vertical line shows the median $\left(T_{50}\right)$. The box frame is limited to the 25th and 75th percentiles and the box whiskers show the 10th and 90th percentiles. The remaining percentiles (1st-9th, 91st-100th) are shown as individual data points with filled blue circles.

resenting the ice-active mass site density (Fig. 3). Without dividing by TOC, Eq. (1) results in the number of IN sites, which is also plotted in Fig. 3. Note that the TOC content was calculated based on the $50 \%$ carbon content by mass as specified from the vendor's elemental analysis (Sect. 2.1). Uncertainties in the TOC content were quantified based on sample preparation, and included the balance $( \pm 0.01 \mathrm{mg})$ and the volumetric flask $( \pm 0.06 \mathrm{~mL})$ and illustrated as error bars in Fig. 4c. An additional discussion of errors related to $n_{\mathrm{m}}$ can be found in the Supplement (Sect. S5).

$n_{\mathrm{m}}=-\frac{\ln (1-\mathrm{FF})}{\mathrm{TOC} \times V_{\text {well }}}$

\subsubsection{Data visualization}

FINC data analysis was conducted in MATLAB ${ }^{\circledR}$. In addition to the two-dimensional FF curve graphs and $n_{\mathrm{m}}$, boxplots are used to visualize freezing data. The advantage of boxplots is that one dimension is sufficient per experiment to show temperature-dependent freezing events, which enables a clear and concise data presentation of experiments side by side (Fig. 3) as established in, for example, Brennan et al. (2020). 

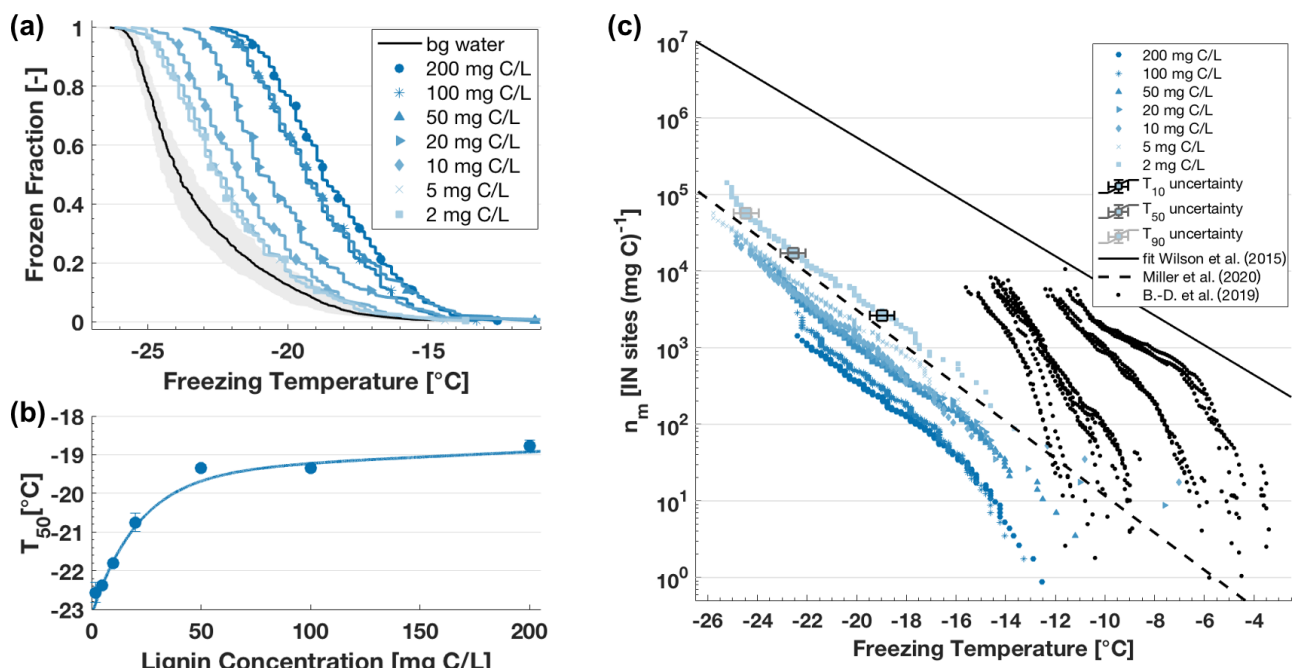

Figure 4. (a) Frozen fraction (FF) curves as a function of temperature for an aqueous dilution series of lignin. The FF curve graph includes the water background (bg water, black line) and its uncertainty range (shaded grey area) representing FINC's limit of detection (see Fig. S6). The temperature uncertainty in each well is $\pm 0.5^{\circ} \mathrm{C}$ and measurement reproducibility is within this range (see Fig. S7). (b) Median freezing temperature $\left(T_{50}\right)$ of the lignin solution as a function of lignin concentration. The $T_{50}$ values include the standard deviation from multiple experiments where applicable $(n \geq 2)$ and are fitted with $T_{50}=-3.7 \times \exp (-0.046 \times x)-19.46 \times \exp (-0.00014 \times x) ; R^{2}=0.99$. Lignin's IN activity in this dilution series remains above the water background and increased exponentially with increasing concentration up to an asymptote around $-19^{\circ} \mathrm{C}$, as illustrated by the slope of the $T_{50}$. (c) Ice-active mass site density $n_{\mathrm{m}}$ as a function of temperature of the aqueous dilution series of lignin. At $T_{10}, T_{50}$ and $T_{90}$ of the $200 \mathrm{mg} \mathrm{C} \mathrm{L}^{-1}$ trace, the freezing temperature $x$-axis uncertainty of $0.5^{\circ} \mathrm{C}$ and uncertainty in $n_{\mathrm{m}}$ based on variation in carbon content are included (see also Fig. S8). Note that the $y$-axis uncertainty is smaller than the limits of the box marker. For comparison, a fit for biogenic particles in sea spray aerosols from Wilson et al. (2015); a lignin parametrization based on $20 \mathrm{mg} \mathrm{C} \mathrm{L}^{-1}$ lignin solutions from Miller et al. (2020), where $n_{\mathrm{m}}=\exp (-0.558 \times T-3.12)$; and $n_{\mathrm{m}}$ values from dissolved organic matter (Borduas-Dedekind et al., 2019) are included.

\section{Results and literature comparison}

\subsection{Lignin as an IN macromolecule}

Lignin was active as an IN macromolecule in the temperature range relevant for mixed-phase clouds. This observation led us to conduct the list of experiments visualized in Fig. 2 to further characterize lignin's IN ability.

\subsubsection{Concentration dependence of lignin's IN ability}

The $50 \%$ frozen fraction $\left(T_{50}\right)$ of lignin solution ranged between $-18.8 \pm 0.15$ and $-22.6 \pm 0.26^{\circ} \mathrm{C}$ for a concentration between $200 \mathrm{mg} \mathrm{C} \mathrm{L}^{-1}\left(40 \mu \mathrm{mol}\right.$ lignin $\left.\mathrm{L}^{-1}\right)$ and $2 \mathrm{mg} \mathrm{C} \mathrm{L}^{-1}$ $\left(0.4 \mu \mathrm{mol}\right.$ lignin $\left.\mathrm{L}^{-1}\right)$, respectively (Fig. 4). Indeed, this dilution series spans 2 orders of magnitude where the expected decreasing trend in IN ability was observed (Fig. 4a). All $T_{50}$ freezing temperatures were above the instrument's limit of detection, derived from averaging 10 background water experiments (black line, Fig. 4a). The frozen fraction values were then normalized by organic carbon content, known from the mass of lignin weighed while making the solutions, to obtain $n_{\mathrm{m}}$ values between -7.6 and $-26.2^{\circ} \mathrm{C}$. The $n_{\mathrm{m}}$ values (Fig. 4c) increased exponentially with decreasing freez- ing temperature and covered more than 5 orders of magnitude between 1 and $10^{5} \mathrm{IN}$ sites $(\mathrm{mg} \mathrm{C})^{-1}$.

Interestingly, we observe a dilution effect after normalization to organic carbon content throughout the series (Fig. 4). In other words, the normalized $n_{\mathrm{m}}$ values of lignin are higher for lower carbon concentrations (Fig. 4c). For example, the $n_{\mathrm{m}}$ values of lignin at $2 \mathrm{mg} \mathrm{C} \mathrm{L}^{-1}$ are a factor of 10 higher than the $n_{\mathrm{m}}$ values of lignin at $200 \mathrm{mg} \mathrm{CL}^{-1}$. In fact, the $T_{50}$ values increased exponentially with an asymptote reaching approximately $-19^{\circ} \mathrm{C}$ with lignin concentrations higher than $50 \mathrm{mg} \mathrm{C} \mathrm{L}^{-1}$ (Fig. 4b). We interpret this result as a change in chemistry of the ice active sites of the macromolecules due to dilution effects and suspect that changes in the supramolecular structure are occurring (Sect. 4.1).

When comparing our obtained $n_{\mathrm{m}}$ values for lignin's dilution series, we note that the data fit closely to the lignin parametrization developed in Miller et al. (2020) based on a $20 \mathrm{mg} \mathrm{C} \mathrm{L}^{-1}$ lignin solution. This agreement underscores the reproducibility within lignin's IN activity and FINC at the same concentration. In addition, the $n_{\mathrm{m}}$ values have the same slope as the IN parametrization for biogenic particles in sea spray aerosols from Wilson et al. (2015) (Fig. 4c) but are 2 orders of magnitude lower than the parametrization. In comparison with $n_{\mathrm{m}}$ values from river and swamp dissolved organic matter (Borduas-Dedekind et al., 2019), lignin's IN 


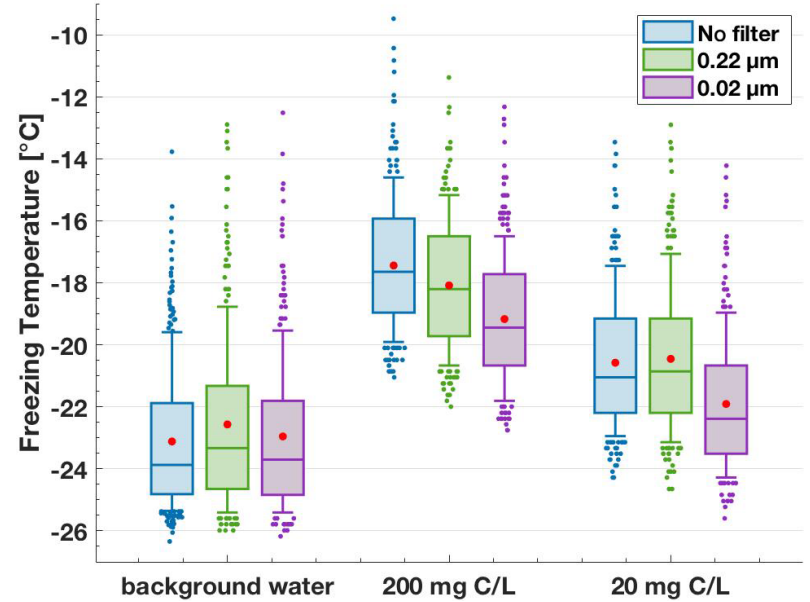

Figure 5. Freezing temperature boxplots for the size filtration series. Aqueous lignin solutions of 200 and $20 \mathrm{mg} \mathrm{C} \mathrm{L}^{-1}$ concentration were filtered through 0.22 and $0.02 \mu \mathrm{m}$ sterile syringe filters. The filtration step reduced the $T_{50}$ values; however, the measured IN activity remained above the background for all samples.

ability is also lower. Both comparisons indicate that although lignin may contribute to the IN activity in organic matter, it is not the most active component within organic matter. This finding is also consistent with Steinke et al. (2020), who identified lignin to have lower IN activity than other plant material collected from dry leaf debris from either spruce or maple trees and agricultural dust after rye and wheat harvests.

\subsubsection{Size dependence of lignin's IN ability}

Filtering aqueous solutions of lignin through sterile syringe filters with pore sizes of 0.22 and $0.02 \mu \mathrm{m}$ reduced the IN activity (Fig. 5). Specifically, the $T_{50}$ freezing temperatures of the filtrate of the $200 \mathrm{mg} \mathrm{C} \mathrm{L}^{-1}$ lignin solution decreased by $0.6^{\circ} \mathrm{C}$ with the $0.22 \mu \mathrm{m}$ filter and by $1.9^{\circ} \mathrm{C}$ with the $0.02 \mu \mathrm{m}$ filter compared to the unfiltered sample. On the other hand, the $20 \mathrm{mg} \mathrm{C} \mathrm{L}^{-1}$ solutions showed a decrease of $1.3^{\circ} \mathrm{C}$ in the $T_{50}$ value only after filtration through $0.02 \mu \mathrm{m}$. Notably, these $0.02 \mu \mathrm{m}$ filtered lignin solutions still showed IN activity higher than the water background by $1.3^{\circ} \mathrm{C}$, indicating that the remaining macromolecules of sizes $<0.02 \mu \mathrm{m}$ were still active in nucleating ice via immersion freezing. In fact, all solutions after filtering remained IN active above the water background. This result illustrates how the polymers vary in size beyond the limit of the filters used and that every size bin investigated here contributes to lignin's IN activity. Thus, the decrease in IN activity after filtering can be attributed to the loss of mass, i.e. a concentration decrease (Sect. 3.1.1), rather than to the loss of particularly active size fractions of lignin.

Further, we highlight the contribution of the lignin components $<0.02 \mu \mathrm{m}$ in comparison to similar filtering experiments of INP samples collected in the field. In samples col- lected from the sea-surface microlayer (Irish et al., 2017; Wilson et al., 2015), IN activity was retained after filtering through $0.22 \mu \mathrm{m}$ filters but reduced to the background level after filtering through $0.02 \mu \mathrm{m}$. The ice-nucleating material was further characterized as likely biogenic. The same reduction to the background level after filtering through $0.02 \mu \mathrm{m}$ was also observed Brennan et al. (2020), who investigated the IN ability of alpine snowmelt samples. In these studies, the INP size range was confined to $0.22-0.02 \mu \mathrm{m}$, which means lignin was not present in appreciable concentrations due to the lack of activity below $0.02 \mu \mathrm{m}$. However, we could now show that this lower limit of $0.02 \mu \mathrm{m}$ cannot be generalized to describe IN macromolecules from complex organic samples universally. If IN activity remains after filtering through $0.02 \mu \mathrm{m}$, this activity could be attributed to fractions of lignin as a particular subcomponent of organic matter.

\subsection{Effects of physicochemical treatments on lignin's IN ability}

We investigated the effects of physicochemical treatments typically used in atmospheric ice nucleation research to deconvolute the source identities of ambient INP samples, including sonication, heating and reaction with hydrogen peroxide. In particular, heating and the reaction with hydrogen peroxide have been used frequently to remove organic material including biological material from IN samples (e.g. (Conen et al., 2011; Hill et al., 2016; Paramonov et al., 2018; Perkins et al., 2020; Tobo et al., 2014).

\subsubsection{Effect of sonication}

Sonication is a common extraction tool to remove particulate matter from filters. As Miljevic et al. (2014) showed, this process can produce reactive radicals which may impact the aerosol's chemical composition. We therefore investigated if sonication could affect lignin's IN activity. Aqueous lignin solutions concentrated at 200 and $20 \mathrm{mg} \mathrm{C} \mathrm{L}^{-1}$ were sonicated for up to $60 \mathrm{~min}$. After $60 \mathrm{~min}$, this treatment did not introduce a distinct change in lignin's IN activity resulting from reactive radicals produced (Fig. S9). Based on these observations, the effect of pre-treating or extracting organic aerosol samples using sonication is predicted to have no impact on lignin's IN activity.

\subsubsection{Effect of heating}

Heating procedures are commonly used to remove the contributions of organic matter including biological material to IN activity in complex samples containing mixtures of heatlabile and heat-stable material. We heated dry lignin in an oven at a range of temperatures up to $300^{\circ} \mathrm{C}$ for $3 \mathrm{~h}$ before dissolving the powder in background water. We only observed a decrease in lignin's IN activity after exposure to temperatures above $180^{\circ} \mathrm{C}$ (Fig. 6). In particular, at $260^{\circ} \mathrm{C}$, the IN activity was reduced to the background water level 


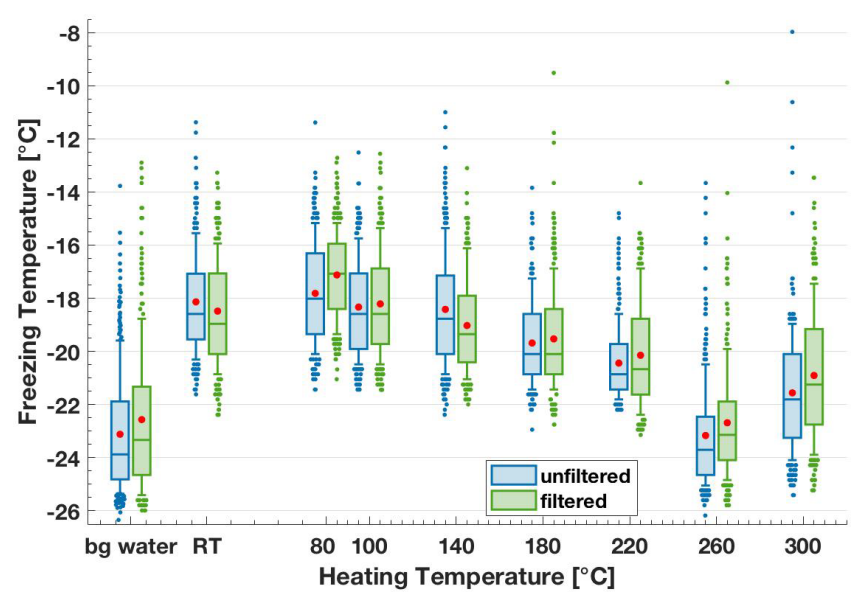

Figure 6. Freezing temperature boxplots of the $200 \mathrm{mg} \mathrm{C} \mathrm{L}^{-1}$ lignin solutions directly after heating (blue, unfiltered) and after filtering through a sterile syringe filter of $0.22 \mu \mathrm{m}$, PES membrane, TPP (green, filtered). "Bg water" refers to background water, "RT" refers to room temperature, i.e. $20^{\circ} \mathrm{C}$. Irrespective of the filtering, lignin's IN activity decreases after a heating treatment of $180^{\circ} \mathrm{C}$ or higher.

with a $T_{50}$ value of $-23.7^{\circ} \mathrm{C}$. Therefore, to completely remove the contributions from lignin to IN activity in ambient samples, a temperature above $260^{\circ} \mathrm{C}$ is necessary. It is likely that when heat-stable organic fractions have been observed in complex samples after a heat treatment $<260^{\circ} \mathrm{C}$, lignin fragments were contributing to the remaining IN activity (e.g. in Hill et al., 2016; Suski et al., 2018). Note that we observed an unexpected increase in the $T_{50}$ value to $-21.8^{\circ} \mathrm{C}$ for a heating temperature of $300^{\circ} \mathrm{C}$, challenging the decreasing trend in IN activity. However, the reason for this increase at $300^{\circ} \mathrm{C}$ remains unclear.

The mass of lignin was weighed before and after the heating treatment and the weighted mass loss of lignin powder below $0.01 \mathrm{wt} \%$. Thus, the observed decrease in IN activity is not due to a decrease in the total lignin concentration (Sect. 3.1.1). With increasing heating temperatures, the lignin powder visually darkened and became insoluble. As a result, the experimental solutions contained visible suspensions of lignin from exposure to $220^{\circ} \mathrm{C}$ and higher. Therefore, heating altered the polymer's chemical structure, which affected the IN activity and the solubility. Indeed, these temperature-dependent structural modifications have been studied in detail previously. For example, Kim et al. (2014b, a) heated milled wood lignin to between 150 and $300^{\circ} \mathrm{C}$ and analysed modifications in the functional group composition using chromatography methods, nitrobenzene oxidation and NMR (nuclear magnetic resonance). Briefly, the results from this study showed that from a heating temperature of $150^{\circ} \mathrm{C}$, first ether bonds connecting methoxyl groups to aromatic rings within the polymer are broken and then bonds to increasingly bigger side-chains and terminal func- tional groups are cleaved. Starting at $250^{\circ} \mathrm{C}$, depolymerization occurred, including breakage of ether bonds releasing monomeric phenols. Simultaneously, condensation reactions took place, which reconnected the lignin fragments to modified polymeric structures.

To further test whether the soluble or insoluble lignin can both act as the ice-nucleating macromolecule or particle, respectively, we filtered the suspensions with sterile syringe filtration using $0.22 \mu \mathrm{m}$ PES membrane (TPP) filters and measured the IN ability of the filtrate on FINC (Fig. 6). Note that attempted vacuum filtrations with $0.22 \mu \mathrm{m}$ MCE membrane (MF-Millipore) filters led to elevated background water freezing temperatures, so their use was discontinued. We find consistently that the $T_{50}$ values of the filtrate were the same as the unfiltered heated lignin suspension (Fig. 6). Therefore, the insoluble mass lost through filtering was not responsible for the remaining IN activity, further confirming the role of the soluble fraction to the IN activity. We can be sure that the lignin concentration was lower in the filtrate solutions, since the filtration step removed mass. Thus, the heated and filtered soluble lignin had a higher IN activity compared to the insoluble lignin, further distinguishing IN macromolecule and IN particles. This IN activity could be due to changes in the chemical structure or due to the dilution that may change lignin's supramolecular structure in solution, as discussed in Sects. 3.1.1 and 4.1.

\subsubsection{Effect of reactions with hydrogen peroxide}

We exposed lignin to increasing concentrations of hydrogen peroxide for $24 \mathrm{~h}$; we then diluted the solution with background water to match $200 \mathrm{mg} \mathrm{C} \mathrm{L}^{-1}$ and subsequently measured the freezing temperatures with FINC (Fig. S11). Additionally, we tested prolonged reaction time up to $4 \mathrm{~d}$, which did not affect the freezing temperature results as illustrated in Fig. S10. This control was necessary as there were no reliable indicators to show the completion of the reaction with hydrogen peroxide after the bubbling and frothing of the sample had subsided (Mikutta et al., 2005; Paramonov et al., 2018). In all, lignin's IN ability decreased at a ratio of $1 \mathrm{~g}$ lignin to $200 \mathrm{~mL} \mathrm{H}_{2} \mathrm{O}_{2}$ and larger (Fig. S11). Thus, lignin is robust under hydrogen peroxide treatment and an exposure of at least 50 times molar excess of hydrogen peroxide to carbon is required to induce oxidative effects that lead to changes in the polymer's IN activity.

The necessary hydrogen peroxide concentration to observe a change in lignin is not directly transferable to lignin's decomposition in complex IN samples. In complex ambient organic samples, other hydrogen peroxide reaction pathways, e.g. involving metal ion catalysts or other reactive intermediates, are potentially available to break down the molecule (Mikutta et al., 2005). With insufficient amounts of oxidant, organic residuals may contain lignin which continues to contribute to observed IN activity after a hydrogen peroxide chemical treatment (e.g. in Paramonov et al., 2018; Suski et 
al., 2018). Specifically, Paramonov et al. (2018) treated their ambient soil IN samples in the ratio of $1 \mathrm{~g}$ material to $5 \mathrm{~mL}$ $\mathrm{H}_{2} \mathrm{O}_{2}(35 \mathrm{wt} \%)$. Even though the sample carbon content was low with a maximum of $2.3 \%$, these conditions only equate to an excess of $\sim 27$ times molar excess of hydrogen peroxide to carbon. Thus, that amount of oxidant would likely not have been enough to completely oxidize lignin in the samples to remove its contribution to IN activity. We conclude that lignin's recalcitrance should be considered when developing methods to remove all organic carbon from complex IN samples.

At concentrations of hydrogen peroxide exceeding the ratio $1 \mathrm{~g}$ lignin: $200 \mathrm{~mL} \mathrm{H}_{2} \mathrm{O}_{2}$, an odd freezing point depression from hydrogen peroxide decreased the $T_{50}$ values rapidly down to the $T_{50}$ value of a pure $\mathrm{H}_{2} \mathrm{O}_{2}$ background solution, which was reached at the ratio of $1 \mathrm{~g}$ lignin to $750 \mathrm{~mL} \mathrm{H}_{2} \mathrm{O}_{2}$ (Fig. S11). The cause of this effect is not fully understood (Sect. S7) but hinders more detailed interpretations of the freezing temperature results for this chemical treatment. Attempts to further quantify chemical changes to lignin via ${ }^{1} \mathrm{H}$ and ${ }^{13} \mathrm{C}$ NMR were unsuccessful due to lack of mass and thus signal. Further, in UV-Vis spectrometer measurements, lignin's signal overlapped with the absorbance of $\mathrm{H}_{2} \mathrm{O}_{2}$ in the relevant wavelength range of 400-200 nm (Fig. S12; Vaghjiani and Ravishankara, 1989).

\subsection{Effects of atmospheric processing on lignin's IN activity and chemical structure}

Organic aerosols have an average atmospheric lifetime of days to weeks. During this time, the aerosols will be subject to atmospheric processing, which can include photochemistry resulting from exposure to sunlight or other reactions involving atmospheric oxidants such as ozone. Atmospheric processing causes ageing of the aerosols, altering their physical and chemical properties. For example, photochemical processing degrades chromophores. These changes may subsequently have an impact on their IN activity (Attard et al., 2012; Borduas-Dedekind et al., 2019; Gute and Abbatt, 2018; Kunert et al., 2019). To observe possible impacts of atmospheric processing on lignin's IN activity, we conducted photochemical experiments and reactions with ozone. To track possible structural changes, we measured UV-Vis spectra and followed the production of small low-weight organic acids resulting from photochemical decay with IC (ion chromatography).

\subsubsection{Effect of photochemistry on lignin's IN activity}

Lignin samples concentrated at $20 \mathrm{mgC} \mathrm{L}^{-1}$ were subjected to UVB irradiation for up to $25 \mathrm{~h}$ in a photoreactor, corresponding to approximately $6.5 \mathrm{~d}$ in the atmosphere (Sect. S3). After this photochemical exposure, the change in $T_{50}$ value was less than $-1{ }^{\circ} \mathrm{C}$ (Fig. S13). Overall, we calculated a weak decreasing trend in freezing temperatures with increasing irradiation with a weak correlation coefficient of -0.65 (with $p=0.023$ ). A repeated $25 \mathrm{~h}$ exposure experiment reproduced these results. We conclude that lignin is recalcitrant to photochemical degradation, despite its ability to act as a chromophore.

We emphasize the lack of decrease in lignin's IN activity by photochemistry as recent studies on pollen (Gute and Abbatt, 2018) and dissolved organic matter have shown otherwise (Borduas-Dedekind et al., 2019). Specifically, Gute and Abbatt (2018) investigated the effect of indirect photochemical oxidation with the hydroxyl radical on the IN activity of birch and grey alder sub-pollen particles. This study linked the exposure to $\mathrm{OH}$ radicals to a decrease in IN activity of pollen. Similarly, Borduas-Dedekind et al. (2019) subjected naturally occurring dissolved organic matter to photochemical processing and found that its ability to nucleate ice decreased at a loss rate of $-0.04{ }^{\circ} \mathrm{C}_{50} \mathrm{~h}^{-1}$. In contrast, lignin's IN activity was resistant to atmospherically relevant photochemical processing and is likely to be retained throughout lignin's lifetime in the atmosphere in the absence of other deactivating and degradation processes.

\subsubsection{Effect of ozone exposure on lignin's IN activity}

To simulate the atmospheric processing of lignin by $\mathrm{O}_{3}$, we exposed bulk solutions concentrated at $20 \mathrm{mg} \mathrm{C} \mathrm{L}^{-1}$ to a gas flow containing $100 \mathrm{ppbv}$ and $1 \mathrm{ppmv}$ of $\mathrm{O}_{3}$ for up to $2 \mathrm{~h}$. This exposure did not affect lignin's IN activity significantly (Fig. S14); the $T_{50}$ values changed by $0.7^{\circ} \mathrm{C}$ with $100 \mathrm{ppbv}$ $\mathrm{O}_{3}$ and by $0.4^{\circ} \mathrm{C}$ with 1 ppmv $\mathrm{O}_{3}$, values approaching to the temperature uncertainty in FINC. Furthermore, we tested longer exposure times, but we observed no further change in $T_{50}$ during an exposure duration of $6.5 \mathrm{~h}$ with an $\mathrm{O}_{3}$ concentration of $1 \mathrm{ppmv}$, indicating lignin's stability towards ozone oxidation.

We argue that our experimental setup with bulk solutions represents an upper limit for the reactivity of lignin towards $\mathrm{O}_{3}$ in the atmosphere. The bubbling of a flow of $\mathrm{O}_{3}$ within the solution is not directly comparable to atmospheric gas-phase $\mathrm{O}_{3}$ partitioning. Indeed, bubbling supplies a larger water-air interface, thereby increasing the partitioning of gaseous $\mathrm{O}_{3}$ into solution, leading to higher dissolved $\mathrm{O}_{3}$ concentrations in our experimental setup. Nevertheless, the lack of change in freezing temperatures during these experiments further illustrates the recalcitrance of lignin's IN activity. Tropospheric $\mathrm{O}_{3}$ concentrations average around $35-40$ ppbv globally and rarely reach $100 \mathrm{ppbv}$, even in more polluted regions ( $\mathrm{Ti}^{-}$ wari and Agrawal, 2018). Thus, atmospheric processing by $\mathrm{O}_{3}$ likely does not influence lignin's IN activity. This stability in IN activity after oxidation by $\mathrm{O}_{3}$ up to $1 \mathrm{ppm}$ and $6 \mathrm{~h}$ duration was also observed by Kunert et al. (2019) and by Attard et al. (2012), who investigated fungal and bacterial ice nuclei, respectively. Notably, the oxidative gas mixtures in both of these studies additionally contained nitrogen dioxide 


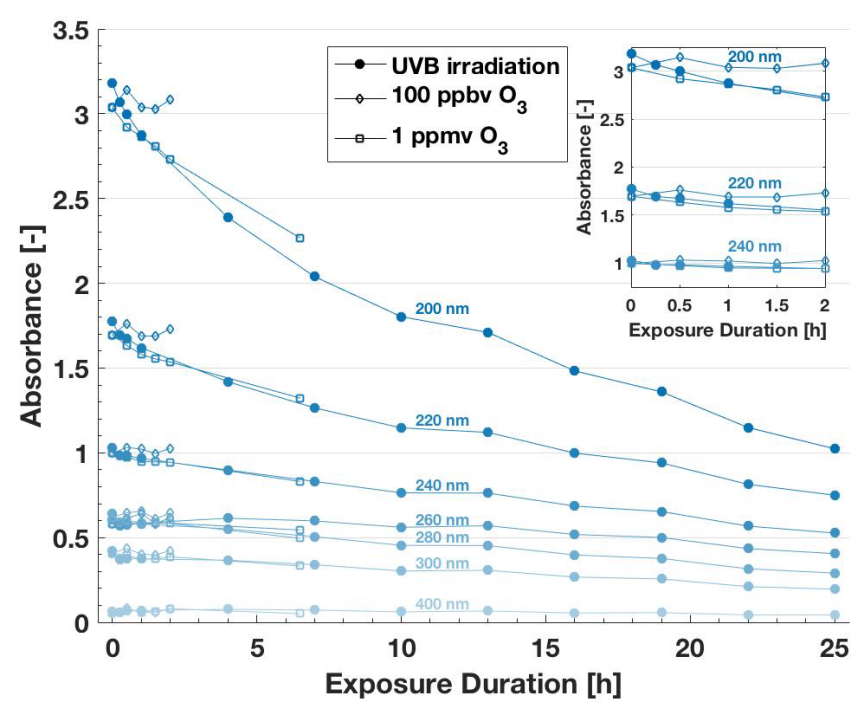

Figure 7. Wavelength-specific absorbance values from UV-Vis spectra of $20 \mathrm{mg} \mathrm{C} \mathrm{L}^{-1}$ lignin solutions after atmospheric processing through UVB irradiation and exposure to $\mathrm{O}_{3}$. The insert zooms in on the section from 0 to $2 \mathrm{~h}$ exposure duration. With increasing exposure duration, lignin's absorbance decreases. Changes after exposure to $100 \mathrm{ppbv} \mathrm{O}_{3}$ are minimal.

$\left(\mathrm{NO}_{2}\right)$ as a second oxidant in the same concentration as $\mathrm{O}_{3}$ and still no significant effect was observed.

\subsubsection{Chemical changes in lignin through atmospheric processing}

Changes in the absorption spectrum of lignin in the UV-Vis range revealed that both the photochemical processing and the reaction with 1 ppmv $\mathrm{O}_{3}$ affected the polymer's chemical structure (Fig. 7). In both treatments, the absorbance decreased throughout the measured range of wavelengths with longer exposure duration, especially at the distinctive absorbance peaks around 205, 230 and $280 \mathrm{~nm}$ (Fig. S15). This decrease indicates the decay of chromophores in lignin, which are mostly conjugated aromatic systems present in the monolignols (Huang et al., 2019). Interestingly, the observed decrease in absorbance matches closely in both experiments, indicating that the same functional groups were affected by photochemistry.

The preliminary analysis of the TOC content (Sect. S5) showed a potential average decrease of $25 \%$ by weight after $25 \mathrm{~h}$ of UVB irradiation. However, we know that this decrease is not large enough to substantially influence our interpretation of ice-nucleating activity after normalization to carbon content (Fig. S8). Furthermore, we tracked the production of photoproducts formed from the chromophoric decay of the polymer, including formic acid, acetic acid and oxalic acid. Indeed, these oxidation products increased in concentration with exposure duration (Fig. S16). However, neither the decay of chromophores nor the resulting production of these small low-weight organic acids affected IN characteristics (Sect. 3.3.1 and 3.3.2). Thus, the chromophoric substructures of lignin reactive to UVB light or ozone are not responsible for the observed IN activity of lignin. Alternatively, the new structures resulting from the atmospheric processing may be equally active in nucleating ice. Both conclusions underscore how lignin acts as an especially robust IN macromolecule that is recalcitrant to the effect of structural changes.

\section{Discussion}

\subsection{Lignin's supramolecular structure in solution}

The results of the dilution series (Sect. 3.1.1) show that the concentration dependence of lignin's IN activity is nonlinear. After normalization to carbon concentration, the $n_{\mathrm{m}}$ values increase with decreasing lignin concentration (Fig. 4c). We interpret this result as evidence for changes in lignin's supramolecular structure. Indeed, it has already been shown how the supramolecular shape of dissolved molecules can influence important aerosol properties including ice nucleation (Cascajo-Castresana et al., 2020; Pfrang et al., 2017; Qiu et al., 2019). For example, light diffusion and viscosity change depending on the supramolecular structure which in turn has implications for reaction rates within the aerosol and cloud nucleation processes (Pfrang et al., 2017). Further, CascajoCastresana et al. (2020) showed how pH-dependent protein aggregation influences the freezing temperature regimes observed. The supramolecular structure of lignin in solution specifically is dictated by interactions with the solvent and intra- and intermolecular forces within the polymers (Huang et al., 2019; Vainio et al., 2004). Additionally, the source of lignin, the presence of other solutes, the temperature, and the solution $\mathrm{pH}$ exert important influences on the supramolecular structure (Huang et al., 2019) and can lead to the presence of clusters and agglomerates (Norgren et al., 2001; Norgren and Edlund, 2001; Vainio et al., 2004). We hypothesize that lignin is indeed aggregating in our aqueous solutions. In a cloud droplet, lignin may interact via hydrogen bonding with water helping stabilize the ice embryo (Kanji et al., 2017) and promote ice nucleation. As the concentration of lignin decreases, the probability for intramolecular interactions within the polymer decreases. The biopolymer is less likely to form aggregates and could instead be unfolding to interact with more water molecules. Thus, at lower concentrations, the relative IN activity is increased as the additional interactions promote ice nucleation. The implication of this result is important for the interpretation of dilution series in immersion freezing experiments.

\subsection{Use of commercial lignin}

One of the caveats of our work is the use of commercially available kraft lignin as our source material. Kraft lignin is 
not naturally occurring lignin but rather a by-product of the pulp and paper industry. Thus, there are differences in the structure of the lignin we used compared to native lignin in plants (Giummarella et al., 2020). Notably, every isolation method currently available introduces changes to the structure of lignin, complicating the observation of the biopolymer in its native state (Chung and Washburn, 2016; Stark et al., 2016). The kraft process in particular fragments the polymer and increases its solubility compared to natural lignin to separate it from the pulp. Additionally, sulfur is used, which introduces thiol groups as a minor impurity into the polymeric structure. Consequently, there could be differences between the behaviour of natural and kraft lignin as IN macromolecules. Further experiments will be conducted to investigate the importance of this issue. Nonetheless, the polymer backbone structures of native and kraft lignin remain highly related, and we do not expect large differences in the IN activity. We argue that native lignin would also be recalcitrant in the atmosphere and therefore has an extended lifetime within the aerosol while retaining its ice-nucleating ability in immersion mode.

\subsection{Atmospheric implications}

Lignin is a subcomponent of organic matter in aerosols and soils and is capable of nucleating ice in mixed-phase cloud conditions. Specifically, $n_{\mathrm{m}}$ values for lignin solutions ranged from 1 to $10^{5} \mathrm{IN}$ sites $(\mathrm{mg} \mathrm{C})^{-1}$ between -7.6 to $-26.2^{\circ} \mathrm{C}$, representing $1-2$ orders of magnitude lower values than dissolved organic matter samples (Borduas-Dedekind et al., 2019; Knackstedt et al., 2018; Moffett et al., 2018), seasurface microlayer samples (Irish et al., 2017; Wilson et al., 2015) and plant extracts (Gute and Abbatt, 2018; Steinke et al., 2020). However, lignin concentrations in the atmosphere have been estimated to be up to $150 \mathrm{ng} \mathrm{m}^{-3}$ after events related to biomass burning (Myers-Pigg et al., 2016). Lignin is therefore likely more abundant in the atmosphere, especially during biomass burning events, compared to other plant extracts and bioaerosols, despite being less ice active. Another quantitative estimate for lignin's relevance in the atmosphere is based on quantification of atmospheric plant debris. For example, Sánchez-Ochoa et al. (2007) reported annual average concentrations of plant debris between 33.4 and $363 \mathrm{ng} \mathrm{m}^{-3}$ depending on the sampling location. Puxbaum and Tenze-Kunit (2003) reported an average of $750 \mathrm{ng} \mathrm{m}^{-3}$ of plant debris and of $374 \mathrm{ng} \mathrm{m}^{-3}$ of cellulose over a time series of 9 months at an urban sampling location. As lignin and cellulose are related biopolymers, these values may provide an upper limit for a concentration range of atmospheric lignin.

Furthermore, lignin's IN ability shows resistance to physicochemical treatments and atmospheric processing despite structural changes in the chromophoric substructures that were observed by UV-Vis absorbance. Only harsh treatment conditions such as heating above $260^{\circ} \mathrm{C}$ reduced lignin's IN ability in immersion-mode freezing to FINC's limit of detection. We link the source of lignin's stability to the lack of labile functional groups in its structure (Fig. 1). For example, the carbon backbone of the polymer is strong, and the ester and ether groups would require harsh acid hydrolysis to be broken apart. We emphasize that due to this robustness, lignin can likely be part of heat-stable components that are observed after heating treatments of complex organic INP samples. Overall, lignin's observed stability implies that lignin present in aerosols is a particularly long-lived organic component and may contribute to the aerosol's overall IN activity throughout its atmospheric lifetime. Notably, the IN ability of lignin will change during the aerosol's lifetime, as water evaporation or condensation cycles affect the polymer's concentration and consequently its macromolecular structure.

Data availability. Data presented in all figures in the main text and in the Supplement are deposited in the ETH Research Collection data repository at https://doi.org/10.3929/ethz-b-000422111 (Borduas-Dedekind and Bogler, 2020).

Supplement. The supplement related to this article is available online at: https://doi.org/10.5194/acp-20-14509-2020-supplement.

Author contributions. SB and NBD designed the experiments, and SB carried them out. SB and NBD prepared the article together.

Competing interests. The authors declare that they have no conflict of interest.

Acknowledgements. We acknowledge the help of Rachele Ossola with the actinometry experiments, the technical help of Michael Rösch for FINC maintenance and the assistance of Franz Friebel in developing the ozone oxidation setup. We also thank Nadine Borduas-Dedekind group members Anna Miller and Silvan Müller for insightful discussions and feedback.

Financial support. This research has been supported by the Swiss National Science Foundation (grant no. PZ00P2_179703).

Review statement. This paper was edited by Manabu Shiraiwa and reviewed by two anonymous referees. 


\section{References}

Attard, E., Yang, H., Delort, A.-M., Amato, P., Pöschl, U., Glaux, C., Koop, T., and Morris, C. E.: Effects of atmospheric conditions on ice nucleation activity of Pseudomonas, Atmos. Chem. Phys., 12, 10667-10677, https://doi.org/10.5194/acp-12-106672012, 2012.

Augustin-Bauditz, S., Wex, H., Denjean, C., Hartmann, S., Schneider, J., Schmidt, S., Ebert, M., and Stratmann, F.: Laboratorygenerated mixtures of mineral dust particles with biological substances: characterization of the particle mixing state and immersion freezing behavior, Atmos. Chem. Phys., 16, 5531-5543, https://doi.org/10.5194/acp-16-5531-2016, 2016.

Axson, J. L., May, N. W., Colón-Bernal, I. D., Pratt, K. A., and Ault, A. P.: Lake Spray Aerosol: A Chemical Signature from Individual Ambient Particles, Environ. Sci. Technol., 50, 9835-9845, https://doi.org/10.1021/acs.est.6b01661, 2016.

Birkel, U., Gerold, G., and Niemeyer, J.: Abiotic reactions of organics on clay mineral surfaces, in: Developments in Soil Science, edited by: Violante, A., Huang, P. M., Bollag, J.-M., and Gianfreda, L., Elsevier, Amsterdam, the Netherlands, 437-447, 2002.

Boerjan, W., Ralph, J., and Baucher, M.: Lignin Biosynthesis, Annu. Rev. Plant Biol., 54, 519-546, https://doi.org/10.1146/annurev.arplant.54.031902.134938, 2003.

Bogler, S. and Borduas-Dedekind, N.: Lignin's ability to nucleate ice via immersion freezing and its stability towards physicochemical treatments and atmospheric processing, ETH Zurich, https://doi.org/10.3929/ethz-b-000422111, 2020.

Bond, T. C., Doherty, S. J., Fahey, D. W., Forster, P. M., Berntsen, T., DeAngelo, B. J., Flanner, M. G., Ghan, S., Kärcher, B., Koch, D., Kinne, S., Kondo, Y., Quinn, P. K., Sarofim, M. C., Schultz, M. G., Schulz, M., Venkataraman, C., Zhang, H., Zhang, S., Bellouin, N., Guttikunda, S. K., Hopke, P. K., Jacobson, M. Z., Kaiser, J. W., Klimont, Z., Lohmann, U., Schwarz, J. P., Shindell, D., Storelvmo, T., Warren, S. G., and Zender, C. S.: Bounding the role of black carbon in the climate system: A scientific assessment, J. Geophys. Res.-Atmos., 118, 5380-5552, https://doi.org/10.1002/jgrd.50171, 2013.

Borduas-Dedekind, N., Ossola, R., David, R. O., Boynton, L. S., Weichlinger, V., Kanji, Z. A., and McNeill, K.: Photomineralization mechanism changes the ability of dissolved organic matter to activate cloud droplets and to nucleate ice crystals, Atmos. Chem. Phys., 19, 12397-12412, https://doi.org/10.5194/acp-1912397-2019, 2019.

Brennan, K. P., David, R. O., and Borduas-Dedekind, N.: Spatial and temporal variability in the ice-nucleating ability of alpine snowmelt and extension to frozen cloud fraction, Atmos. Chem. Phys., 20, 163-180, https://doi.org/10.5194/acp-20-1632020, 2020.

Cascajo-Castresana, M., David, R. O., Iriarte-Alonso, M. A., Bittner, A. M., and Marcolli, C.: Protein aggregates nucleate ice: the example of apoferritin, Atmos. Chem. Phys., 20, 3291-3315, https://doi.org/10.5194/acp-20-3291-2020, 2020.

Chandra, M. R. G. S. and Madakka, M.: Comparative Biochemistry and Kinetics of Microbial Lignocellulolytic Enzymes, in: Recent Developments in Applied Microbiology and Biochemistry, edited by: Buddolla, V., Academic Press, London, UK, 147-159, 2019.
Chung, H. and Washburn, N. R.: Extraction and Types of Lignin, in: Lignin in Polymer Composites, edited by: Faruk, O. and Sain, M., Elsevier, Oxford, UK, 13-25, 2016.

Conen, F., Morris, C. E., Leifeld, J., Yakutin, M. V., and Alewell, C.: Biological residues define the ice nucleation properties of soil dust, Atmos. Chem. Phys., 11, 9643-9648, https://doi.org/10.5194/acp-11-9643-2011, 2011.

Faraji, M., Fonseca, L. L., Escamilla-Treviño, L., Barros-Rios, J., Engle, N., Yang, Z. K., Tschaplinski, T. J., Dixon, R. A., and Voit, E. O.: Mathematical models of lignin biosynthesis, Biotechnol. Biofuels, 11, 34, https://doi.org/10.1186/s13068-018-10289, 2018.

Giummarella, N., Lindén, P. A., Areskogh, D., and Lawoko, M.: Fractional Profiling of Kraft Lignin Structure: Unravelling Insights on Lignin Reaction Mechanisms, ACS Sustainable Chem. Eng., 8, 1112-1120, https://doi.org/10.1021/acssuschemeng.9b06027, 2020.

Gute, E. and Abbatt, J. P.: Oxidative processing lowers the ice nucleation activity of Birch and Alder pollen, Geophys. Res. Lett., 45, 1647-1653, https://doi.org/10.1002/2017GL076357, 2018.

Hill, T. C. J., DeMott, P. J., Tobo, Y., Fröhlich-Nowoisky, J., Moffett, B. F., Franc, G. D., and Kreidenweis, S. M.: Sources of organic ice nucleating particles in soils, Atmos. Chem. Phys., 16, 7195-7211, https://doi.org/10.5194/acp-16-7195-2016, 2016.

Hoose, C. and Möhler, O.: Heterogeneous ice nucleation on atmospheric aerosols: a review of results from laboratory experiments, Atmos. Chem. Phys., 12, 9817-9854, https://doi.org/10.5194/acp-12-9817-2012, 2012.

Huang, J., Fu, S., and Gan, L. (Eds.): Structure and Characteristics of Lignin, in: Lignin Chemistry and Applications, Elsevier, Amsterdam, the Netherlands, 25-50, 2019.

Irish, V. E., Elizondo, P., Chen, J., Chou, C., Charette, J., Lizotte, M., Ladino, L. A., Wilson, T. W., Gosselin, M., Murray, B. J., Polishchuk, E., Abbatt, J. P. D., Miller, L. A., and Bertram, A. K.: Ice-nucleating particles in Canadian Arctic sea-surface microlayer and bulk seawater, Atmos. Chem. Phys., 17, 10583-10595, https://doi.org/10.5194/acp-17-10583-2017, 2017.

Jimenez, J. L., Canagaratna, M. R., Donahue, N. M., Prevot, A. S. H., Zhang, Q., Kroll, J. H., DeCarlo, P. F., Allan, J. D., Coe, H., Ng, N. L., Aiken, A. C., Docherty, K. S., Ulbrich, I. M., Grieshop, A. P., Robinson, A. L., Duplissy, J., Smith, J. D., Wilson, K. R., Lanz, V. A., Hueglin, C., Sun, Y. L., Tian, J., Laaksonen, A., Raatikainen, T., Rautiainen, J., Vaattovaara, P., Ehn, M., Kulmala, M., Tomlinson, J. M., Collins, D. R., Cubison, M. J., E, Dunlea, J., Huffman, J. A., Onasch, T. B., Alfarra, M. R., Williams, P. I., Bower, K., Kondo, Y., Schneider, J., Drewnick, F., Borrmann, S., Weimer, S., Demerjian, K., Salcedo, D., Cottrell, L., Griffin, R., Takami, A., Miyoshi, T., Hatakeyama, S., Shimono, A., Sun, J. Y., Zhang, Y. M., Dzepina, K., Kimmel, J. R., Sueper, D., Jayne, J. T., Herndon, S. C., Trimborn, A. M., Williams, L. R., Wood, E. C., Middlebrook, A. M., Kolb, C. E., Baltensperger, U., and Worsnop, D. R.: Evolution of Organic Aerosols in the Atmosphere, Science, 326, 1525-1529, https://doi.org/10.1126/science.1180353, 2009.

Kanji, Z. A., Ladino, L. A., Wex, H., Boose, Y., BurkertKohn, M., Cziczo, D. J., and Krämer, M.: Overview of Ice Nucleating Particles, Meteorological Monographs, 58, 11133, https://doi.org/10.1175/AMSMONOGRAPHS-D-160006.1, 2017. 
Kim, J.-Y., Hwang, H., Oh, S., Kim, Y.-S., Kim, U.-J., and Choi, J. W.: Investigation of structural modification and thermal characteristics of lignin after heat treatment, Int.J. Biol. Macromol., 66, 57-65, 2014a.

Kim, J.-Y., Hwang, H., Park, J., Oh, S., and Choi, J. W.: Predicting structural change of lignin macromolecules before and after heat treatment using the pyrolysis-GC/MS technique, J. Anal. Appl. Pyrol., 110, 305-312, 2014b.

Knackstedt, K. A., Moffett, B. F., Hartmann, S., Wex, H., Hill, T. C. J., Glasgo, E. D., Reitz, L. A., Augustin-Bauditz, S., Beall, B. F. N., Bullerjahn, G. S., Fröhlich-Nowoisky, J., Grawe, S., Lubitz, J., Stratmann, F., and McKay, R. M. L.: Terrestrial Origin for Abundant Riverine Nanoscale IceNucleating Particles, Environ. Sci. Technol., 52, 12358-12367, https://doi.org/10.1021/acs.est.8b03881, 2018.

Knopf, D. A., Alpert, P. A., and Wang, B.: The Role of Organic Aerosol in Atmospheric Ice Nucleation: A Review, ACS Earth Space Chem., 2, 168-202, https://doi.org/10.1021/acsearthspacechem.7b00120, 2018.

Korolev, A. and Field, P. R.: The Effect of Dynamics on MixedPhase Clouds: Theoretical Considerations, J. Atmos. Sci., 65, 66-86, https://doi.org/10.1175/2007JAS2355.1, 2008.

Kunert, A. T., Pöhlker, M. L., Tang, K., Krevert, C. S., Wieder, C., Speth, K. R., Hanson, L. E., Morris, C. E., Schmale III, D. G., Pöschl, U., and Fröhlich-Nowoisky, J.: Macromolecular fungal ice nuclei in Fusarium: effects of physical and chemical processing, Biogeosciences, 16, 4647-4659, https://doi.org/10.5194/bg16-4647-2019, 2019.

Laszakovits, J. R., Berg, S. M., Anderson, B. G., O’Brien, J. E., Wammer, K. H., and Sharpless, C. M.: p-Nitroanisole/pyridine and p-nitroacetophenone/pyridine actinometers revisited: Quantum yield in comparison to ferrioxalate, Environ. Sci. Tech. Lett., 4, 11-14, https://doi.org/10.1021/acs.estlett.6b00422, 2016.

Lin, S. Y. and Dence, C. W.: Methods in lignin chemistry, Springer Science and Business Media, Berlin, Heidelberg, Germany, 1992.

McCluskey, C. S., DeMott, P. J., Prenni, A. J., Levin, E. J. T., McMeeking, G. R., Sullivan, A. P., Hill, T. C. J., Nakao, S., Carrico, C. M., and Kreidenweis, S. M.: Characteristics of atmospheric ice nucleating particles associated with biomass burning in the US: Prescribed burns and wildfires: Biomass burning ice nucleating particles, J. Geophys. Res.-Atmos., 119, 1045810470, https://doi.org/10.1002/2014JD021980, 2014.

Meyers-Schulte, K. J. and Hedges, J. I.: Molecular evidence for a terrestrial component of organic matter dissolved in ocean water, Nature, 321, 61-63, https://doi.org/10.1038/321061a0, 1986.

Mikutta, R., Kleber, M., Kaiser, K., and Jahn, R.: Review: Organic Matter Removal from Soils using Hydrogen Peroxide, Sodium Hypochlorite, and Disodium Peroxodisulfate, Soil Sci. Soc. Am. J., 69, 120-135, https://doi.org/10.2136/sssaj2005.0120, 2005.

Miljevic, B., Hedayat, F., Stevanovic, S., Fairfull-Smith, K. E., Bottle, S. E., and Ristovski, Z. D.: To Sonicate or Not to Sonicate PM Filters: Reactive Oxygen Species Generation Upon Ultrasonic Irradiation, Aerosol Sci. Tech., 48, 1276-1284, https://doi.org/10.1080/02786826.2014.981330, 2014.

Miller, A. J., Brennan, K. P., Mignani, C., Wieder, J., David, R. O., and Borduas-Dedekind, N.: Development of the drop Freezing Ice Nuclei Counter (FINC), intercomparison of droplet freezing techniques, and use of soluble lignin as an atmo- spheric ice nucleation standard, Atmos. Meas. Tech. Discuss., https://doi.org/10.5194/amt-2020-414, in review, 2020.

Moffett, B. F., Hill, T. C., and DeMott, P. J.: Abundance of biological ice nucleating particles in the Mississippi and its major tributaries, Atmosphere, 9, 307, https://doi.org/10.3390/atmos9080307, 2018.

Mülmenstädt, J., Sourdeval, O., Delanoë, J., and Quaas, J.: Frequency of occurrence of rain from liquid-, mixed-, and ice-phase clouds derived from A-Train satellite retrievals, Geophys. Res. Lett., 42, 6502-6509, https://doi.org/10.1002/2015GL064604, 2015.

Myers-Pigg, A. N., Griffin, R. J., Louchouarn, P., Norwood, M. J., Sterne, A., and Cevik, B. K.: Signatures of Biomass Burning Aerosols in the Plume of a Saltmarsh Wildfire in South Texas, Environ. Sci. Technol., 50, 9308-9314, https://doi.org/10.1021/acs.est.6b02132, 2016.

Norgren, M. and Edlund, H.: Stabilisation of kraft lignin solutions by surfactant additions, Colloid. Surfaces A, 194, 239-248, https://doi.org/10.1016/S0927-7757(01)00806-8, 2001.

Norgren, M., Edlund, H., Wågberg, L., Lindström, B., and Annergren, G.: Aggregation of kraft lignin derivatives under conditions relevant to the process, part I: phase behaviour, Colloid. Surfaces A., 194, 85-96, 2001.

Olson, N. E., May, N. W., Kirpes, R. M., Watson, A. E., Hajny, K. D., Slade, J. H., Shepson, P. B., Stirm, B. H., Pratt, K. A., and Ault, A. P.: Lake Spray Aerosol Incorporated into Great Lakes Clouds, ACS Earth Space Chem., 3, 2765-2774, https://doi.org/10.1021/acsearthspacechem.9b00258, 2019.

Paramonov, M., David, R. O., Kretzschmar, R., and Kanji, Z. A.: A laboratory investigation of the ice nucleation efficiency of three types of mineral and soil dust, Atmos. Chem. Phys., 18, 1651516536, https://doi.org/10.5194/acp-18-16515-2018, 2018.

Perkins, R. J., Gillette, S. M., Hill, T. C. J., and DeMott, P. J.: The Labile Nature of Ice Nucleation by Arizona Test Dust, ACS Earth Space Chem., 4, 133-141, https://doi.org/10.1021/acsearthspacechem.9b00304, 2020.

Pfrang, C., Rastogi, K., Cabrera-Martinez, E. R., Seddon, A. M., Dicko, C., Labrador, A., Plivelic, T. S., Cowieson, N., and Squires, A. M.: Complex three-dimensional self-assembly in proxies for atmospheric aerosols, Nat. Commun., 8, 1724, https://doi.org/10.1038/s41467-017-01918-1, 2017.

Pratt, K. A., DeMott, P. J., French, J. R., Wang, Z., Westphal, D. L., Heymsfield, A. J., Twohy, C. H., Prenni, A. J., and Prather, K. A.: In situ detection of biological particles in cloud ice-crystals, Nature Geosci., 2, 398-401, https://doi.org/10.1038/ngeo521, 2009.

Prenni, A. J., DeMott, P. J., Sullivan, A. P., Sullivan, R. C., Kreidenweis, S. M., and Rogers, D. C.: Biomass burning as a potential source for atmospheric ice nuclei: Western wildfires and prescribed burns: BIOMASS BURNING AS A POTENTIAL IN SOURCE, Geophys. Res. Lett., 39, L11805, https://doi.org/10.1029/2012GL051915, 2012.

Pummer, B. G., Budke, C., Augustin-Bauditz, S., Niedermeier, D., Felgitsch, L., Kampf, C. J., Huber, R. G., Liedl, K. R., Loerting, T., Moschen, T., Schauperl, M., Tollinger, M., Morris, C. E., Wex, H., Grothe, H., Pöschl, U., Koop, T., and Fröhlich-Nowoisky, J.: Ice nucleation by watersoluble macromolecules, Atmos. Chem. Phys., 15, 4077-4091, https://doi.org/10.5194/acp-15-4077-2015, 2015. 
Puxbaum, H. and Tenze-Kunit, M.: Size distribution and seasonal variation of atmospheric cellulose, Atmos. Environ., 37, 36933699, https://doi.org/10.1016/S1352-2310(03)00451-5, 2003.

Qiu, Y., Hudait, A., and Molinero, V.: How Size and Aggregation of Ice-Binding Proteins Control Their Ice Nucleation Efficiency, J. Am. Chem. Soc., 141, 7439-7452, https://doi.org/10.1021/jacs.9b01854, 2019.

Ralph, J., Lapierre, C., and Boerjan, W.: Lignin structure and its engineering, Curr. Opin. Biotech., 56, 240-249, https://doi.org/10.1016/j.copbio.2019.02.019, 2019.

Sánchez-Ochoa, A., Kasper-Giebl, A., Puxbaum, H., Gelencser, A., Legrand, M., and Pio, C.: Concentration of atmospheric cellulose: A proxy for plant debris across a westeast transect over Europe, J. Geophys. Res., 112, D23S08, https://doi.org/10.1029/2006JD008180, 2007.

Shakya, K. M., Louchouarn, P., and Griffin, R. J.: LigninDerived Phenols in Houston Aerosols: Implications for Natural Background Sources, Environ. Sci. Technol., 45, 8268-8275, https://doi.org/10.1021/es201668y, 2011.

Simoneit, B. R. T.: Biomass burning - a review of organic tracers for smoke from incomplete combustion, Appl. Geochem., 17, 129162, https://doi.org/10.1016/S0883-2927(01)00061-0, 2002.

Slade, J. H., VanReken, T. M., Mwaniki, G. R., Bertman, S., Stirm, B., and Shepson, P. B.: Aerosol production from the surface of the Great Lakes: GREAT LAKES AEROSOL PRODUCTION, Geophys. Res. Lett., 37, L18807, https://doi.org/10.1029/2010GL043852, 2010.

Stark, N. M., Yelle, D. J., and Agarwal, U. P.: Techniques for Characterizing Lignin, in: Lignin in Polymer Composites, edited by: Faruk, O. and Sain, M., Elsevier, Oxford, UK, 49-66, 2016.

Stefenelli, G., Jiang, J., Bertrand, A., Bruns, E. A., Pieber, S. M., Baltensperger, U., Marchand, N., Aksoyoglu, S., Prévôt, A. S. H., Slowik, J. G., and El Haddad, I.: Secondary organic aerosol formation from smoldering and flaming combustion of biomass: a box model parametrization based on volatility basis set, Atmos. Chem. Phys., 19, 11461-11484, https://doi.org/10.5194/acp-1911461-2019, 2019.

Steinke, I., Hiranuma, N., Funk, R., Höhler, K., Tüllmann, N., Umo, N. S., Weidler, P. G., Möhler, O., and Leisner, T.: Complex plantderived organic aerosol as ice-nucleating particles - more than the sums of their parts?, Atmos. Chem. Phys., 20, 11387-11397, https://doi.org/10.5194/acp-20-11387-2020, 2020.

Stocker, T. F., Qin, D., Plattner, G.-K., Tignor, M., Allen, S. K., Boschung, J., Nauels, A., Xia, Y., Bex, V., and Midgley, P. M.: Climate change 2013: The physical science basis, Cambridge University Press Cambridge, UK, 2013.

Storelvmo, T., Hoose, C., and Eriksson, P.: Global modeling of mixed-phase clouds: The albedo and lifetime effects of aerosols, J. Geophys. Res., 116, D05207, https://doi.org/10.1029/2010JD014724, 2011.
Suski, K. J., Hill, T. C. J., Levin, E. J. T., Miller, A., DeMott, P. J., and Kreidenweis, S. M.: Agricultural harvesting emissions of ice-nucleating particles, Atmos. Chem. Phys., 18, 13755-13771, https://doi.org/10.5194/acp-18-13755-2018, 2018.

Tiwari, S. and Agrawal, M.: Ozone Concentrations in Troposphere: Historical and Current Perspectives, in: Tropospheric Ozone and its Impacts on Crop Plants: A Threat to Future Global Food Security, edited by: Tiwari, S. and Agrawal, M., Springer, Cham, Switzerland, 1-29, https://doi.org/10.1007/9783-319-71873-6_1, 2018.

Tobo, Y., DeMott, P. J., Hill, T. C. J., Prenni, A. J., SwobodaColberg, N. G., Franc, G. D., and Kreidenweis, S. M.: Organic matter matters for ice nuclei of agricultural soil origin, Atmos. Chem. Phys., 14, 8521-8531, https://doi.org/10.5194/acp14-8521-2014, 2014.

Vaghjiani, G. L. and Ravishankara, A. R.: Absorption cross sections of $\mathrm{CH}_{3} \mathrm{OOH}, \mathrm{H}_{2} \mathrm{O}_{2}$, and $\mathrm{D}_{2} \mathrm{O}_{2}$ vapors between 210 and $365 \mathrm{~nm}$ at $297 \mathrm{~K}$, J. Geophys. Res.-Atmos., 94, 3487-3492, https://doi.org/10.1029/JD094iD03p03487, 1989.

Vainio, U., Maximova, N., Hortling, B., Laine, J., Stenius, P., Simola, L. K., Gravitis, J., and Serimaa, R.: Morphology of Dry Lignins and Size and Shape of Dissolved Kraft Lignin Particles by X-ray Scattering, Langmuir, 20, 9736-9744, https://doi.org/10.1021/la048407v, 2004.

Vali, G.: Quantitative evaluation of experimental results an the heterogeneous freezing nucleation of supercooled liquids, J. Atmos. Sci., 28, 402-409, 1971.

Vali, G.: Repeatability and randomness in heterogeneous freezing nucleation, Atmos. Chem. Phys., 8, 5017-5031, https://doi.org/10.5194/acp-8-5017-2008, 2008.

Vali, G.: Revisiting the differential freezing nucleus spectra derived from drop-freezing experiments: methods of calculation, applications, and confidence limits, Atmos. Meas. Tech., 12, 12191231, https://doi.org/10.5194/amt-12-1219-2019, 2019.

Vanholme, R., De Meester, B., Ralph, J., and Boerjan, W.: Lignin biosynthesis and its integration into metabolism, Curr. Opin. Biotech., 56, 230-239, https://doi.org/10.1016/j.copbio.2019.02.018, 2019.

Wilson, T. W., Ladino, L. A., Alpert, P. A., Breckels, M. N., Brooks, I. M., Browse, J., Burrows, S. M., Carslaw, K. S., Huffman, J. A., Judd, C., Kilthau, W. P., Mason, R. H., McFiggans, G., Miller, L. A., Nájera, J. J., Polishchuk, E., Rae, S., Schiller, C. L., Si, M., Vergara Temprado, J., Whale, T. F., Wong, J. P. S., Wurl, O., Yakobi-Hancock, J. D., Abbatt, J. P. D., Aller, J. Y., Bertram, A. K., Knopf, D. A., and Murray, B. J.: A marine biogenic source of atmospheric ice-nucleating particles, Nature, 525, 234-238, https://doi.org/10.1038/nature14986, 2015.

Zark, M. and Dittmar, T.: Universal molecular structures in natural dissolved organic matter, Nat. Commun., 9, 3178, https://doi.org/10.1038/s41467-018-05665-9, 2018. 